\title{
The Passenger Vessel Services Act and America’s Cruise Tourism Industry
}

\author{
James $\mathrm{Mak}^{\mathrm{a}}$ \\ Department of Economics \\ University of Hawai'i at Manoa \\ Christopher Sheehey ${ }^{\mathrm{b}}$ \\ Department of Economics \\ University of Hawai'i at Manoa \\ and \\ Shannon Toriki ${ }^{\mathrm{c}}$ \\ Department of Economics \\ University of Hawai'i at Manoa
}

November 5, 2009

\begin{abstract}
The Passenger Vessel Services Act (PVSA) of 1886, a cabotage law, attempts to shield U.S. maritime shipping from foreign competition. It also applies to the U.S. cruise ship industry. The PVSA requires foreign cruise ships that carry passengers between U.S. ports to also stop at foreign ports. Norwegian Cruise Line America (NCLA), which operates one U.S. flagged cruise ship in Hawaii, wants the U.S. Customs and Border Protection to require foreign cruise ships offering Hawaii itineraries from the U.S. west coast to spend more time in foreign ports. We analyze the merits of NCLA's proposal. We argue that rather than making the PVSA even more protectionist, the law should be repealed.
\end{abstract}

Keywords: Passenger Vessel Services Act, PVSA, Norwegian Cruise Lines, NCLA, Protectionism, Cruise industry

\footnotetext{
${ }^{a}$ Professor of Economics, University of Hawaii at Manoa, 2424 Maile Way Rm 542, Honolulu, HI 96822, USA. Corresponding author. Tel.: (808) 956-8280; fax: (808) 956-4347; email: jmak@hawaii.edu

${ }^{\mathrm{b}}$ Undergraduate student at University of Hawaii at Manoa

c Undergraduate student at University of Hawaii at Manoa
} 


\title{
THE PASSENGER VESSEL SERVICES ACT AND AMERICA'S CRUISE TOURISM INDUSTRY
}

James Mak ${ }^{\mathrm{a}, 1}$,

Christopher Sheehey ${ }^{b}$

Shannon Toriki ${ }^{b}$

aProfessor of Economics, University of Hawaii at Manoa, 2424 Maile Way Rm 542, Honolulu, HI 96822, USA

${ }^{\mathrm{b}}$ Undergraduate student at University of Hawaii Manoa

\begin{abstract}
Keywords:

Passenger Vessel Services Act

PVSA

Norwegian Cruise Lines

NCLA

Protectionism

Cruise industry
\end{abstract}

The Passenger Vessel Services Act (PVSA) of 1886, a cabotage law, attempts to shield U.S. maritime shipping from foreign competition. It also applies to the U.S. cruise ship industry. The PVSA requires foreign cruise ships that carry passengers between U.S. ports to also stop at foreign ports. Norwegian Cruise Line America (NCLA), which operates one U.S. flagged cruise ship in Hawaii, wants the U.S. Customs and Border Protection to require foreign cruise ships offering Hawaii itineraries from the U.S. west coast to spend more time in foreign ports. We analyze the merits of NCLA's proposal. We argue that rather than making the PVSA even more protectionist, the law should be repealed.

\section{Introduction}

Cruise tourism is one of the fastest growing sectors of global tourism. The Cruise Line International Association (CLIA) estimates that between 1990 and 2007 the number of cruise ship passengers world-wide grew at an average annual rate of 7.4 percent. $^{2}$ In 2007, North America accounted for 82 percent and the U.S. 76 percent of the world's 12.6 million cruise passengers (Ibid.). Cruise lines and their passengers spent more than $\$ 18$ billion in the U.S. economy in 2007. ${ }^{3}$

The cruise tourism business in North America is dominated by companies employing foreign-flagged cruise ships. ${ }^{4}$ U.S. law-the Passenger Vessel Services Act (PVSA) -regulates their ability to transport passengers between U.S. ports (GAO, 2004). The Passenger Vessel

\footnotetext{
${ }^{1}$ Corresponding author. Tel.: (808) 956-8280; fax: (808) 956-4347; email: jmak@hawaii.edu

${ }^{2}$ CLIA (2008) at http://www.cruising.org/Press/overview2008/printPDF.cfm Data for CLIA member cruise lines only. By comparison, international travel and tourism grew at less than 5 percent per year.

${ }^{3}$ Jainchill, October 15, 2008.

${ }^{4}$ The economic implications of flag state registration are discussed in Stopford (1997), pp. 431-440. The "flag" identifies the nationality of the ship. The requirements to flag a ship in the U.S. are among the most stringent among maritime nations (Gibson, 2006, p. 35). Disney and Radisson Seven Seas are U.S. companies which elect to operate foreign-built ships under foreign registry (GAO, 2004, p. 7).
} 
Services Act, a “cabotage” or "coastwise” law, was passed by Congress in $1886 .{ }^{5}$ The law reserves the transportation of passengers between domestic ports to the more-costly U.S.-built and flagged ships staffed by Americans. ${ }^{6}$ A companion law enacted in 1920, commonly referred to as the "Jones Act", applies the same requirements to the transportation of freight (Whitehurst, 1985; White, 1988; Francois, et. al., 1996; and United States International Trade Commission, 2004, pp. 91-98). According to the U.S. Maritime Administration (MARAD), the purposes of such laws "are to assure reliable domestic shipping service and the existence of a maritime capability that is completely subject to national control in times of war or national emergency."7 Transparently, this is achieved by shielding domestic firms from foreign competition. Cabotage laws remain important today in governing the movement of goods and people by air and sea among countries (Mak, 2003; Lewis, 2003; Mak, 2004, Chapter 8).

Current U.S. federal government regulation allows foreign cruise ships to make round trips between U.S. ports and stop along the way at intermediate U.S. ports so long as the ships make a stop at a foreign port and passengers do not leave the trip at one of the intermediate ports (GAO, 2004, p. 5). For example, the popular 7-day round-trip Alaska Inside Passage cruise which stops at several Alaska ports is served only by foreign cruise ships; voyages departing from Seattle, Washington make a brief stop in a Canadian port such as Vancouver or Victoria, British Columbia. Violators are currently subject to a fine of $\$ 300$ for each passenger illegally transported. The foreign port stoppage requirement increases cost to both cruise lines and their passengers. It alters and reduces the cruise options available to consumers. It confers economic rent to U.S. ports that service these cruise ships by virtue of their proximity to foreign ports. For example, many foreign-flagged cruise ships sail from San Diego or Los Angeles to Hawaii and return with a stop in nearby Ensenada, Mexico to comply with the PVSA, but rarely do cruise ships sail from San Francisco to Hawaii. ${ }^{8}$ The PVSA also confers rents to foreign ports at the expense of U.S. ports. ${ }^{9}$

Nobel economist George Stigler observed in his 1971 classic article (Stigler, 1971), "The Theory of Economic Regulation," that “...as a rule, regulation is required by the industry and is designed and operated primarily for its benefit.” In reviewing the effects of over two decades of economic deregulation in selected major industries in the U.S., Winston (1998, p.91) concluded that “...regulation primarily limits competition among firms, and this lack of competition causes an industry to accumulate substantial managerial slack or "X-inefficiency"; that is, firms do not minimize the cost of producing a given level of output.” Since the mid-1970s, Congress has begun a long and slow process of deregulating many industries (Winston, 1998). While the U.S. has also worked hard to lower barriers in international air transportation through the negotiation of “Open Skies” agreements (Mak, 2004, Chapter 8), the U.S. cruise ship industry has not received similar attention and liberalization.

\footnotetext{
${ }^{5}$ The U.S. International Trade Commission (1999, p. 109, footnote \# 83) defines "cabotage” as "the transport of passengers between any two points in the same country."

${ }^{6} \mathrm{GAO}, 2004$. The law also applies to commuter ferry service, riverboat gambling and excursions, and coastal passenger transportation.

${ }^{7}$ MARAD, "By the Capes-A Primer on U.S. Coastwise Laws," p. 2. The U.S. International Trade Commission (2007, p. 96) uses somewhat milder language: “These laws are designed to ensure the existence of a U.S. merchant marine fleet that can participate in domestic oceanborne commerce and can assist in national defense during times of war and national emergency."

${ }^{8}$ In fact, only 1 sailing between 2004 and June 30, 2008.

${ }^{9}$ For example, during the 2009 swine-flu outbreak in Mexico, the PVSA prevented cruise companies from offering U.S.-only itineraries in place of stops in Mexico. (Jainchill, 2009.)
} 
Indeed, a heated controversy is currently brewing over whether the U.S Homeland Security's Bureau of Customs and Border Protection (CBP) should reinterpret the PVSA to increase the amount of time foreign cruise ships must stop in foreign ports in order to carry passengers between U.S. ports. The aim of the proposed reinterpretation is to provide even greater economic protection for U.S. flagged cruise ships. However, there is only one U.S.-flagged cruise ship left in North America to protect, the NorwegianCruise Line America's (NCLA) Pride of America, which offers 7-day weekly cruises among the Hawaiian Islands.

In this paper we study the merits of this proposed rule change. The paper also advances our knowledge of the impact of the Passenger Vessel Services Act on the North American cruise industry. While there exists a substantial body of research on the economic effects of the Jones Act, we are unaware of significant studies on the PVSA. ${ }^{10}$ Section II recounts briefly the history of Norwegian Cruise Line's business in Hawaii and explains why NCLA wants to make even more restrictive the foreign port stoppage rule under the current PVSA. Section III provides details of the proposed rule change submitted by Homeland Security to the White House Office of Management and Budget (OMB) and OMB's reasons for rejecting the application. Section IV provides empirical analysis to ascertain the merits of NCLA's claims. We use U.S. Maritime Administration data on individual cruise ship sailings in North America between 2004 and the second quarter of 2008 as well as data on ticket prices to examine how the expansion of NCLA in Hawaii as well as that of foreign cruise ship sailings to Hawaii from the U.S. west coast affected NCLA's Hawaii interisland cruise business. We demonstrate that NCLA's financial difficulties during its rapid expansion in Hawaii were largely the result of its own doing and not because of alleged "unfair" foreign competition. Indeed, we show that U.S. west coast to Hawaii cruises and NCLA's Hawaii-only interisland cruises are in separate markets. Section V argues that a reinterpretation of the PVSA would not be in the nation's best interest as it would harm consumers, the cruise industry, and U.S. port economies. The paper concludes by suggesting that rather than make the PVSA more restrictive, Congress should consider repealing the PVSA.

\section{Norwegian Cruise Line's Business in Hawaii}

The cruise industry was a latecomer to Hawaii (State of Hawaii, Department of Business, Economic Development and Tourism, circa 2004; Blair \& Mak, 2008). In the 1980s, American Hawaii Cruises, a subsidiary of American Classic Voyages (ACV), began offering interisland cruise itineraries using two 30-year old, small U.S.-built ocean liners, the ss Independence (in 1980) and the ss Constitution (in 1982). In 1984, they were the only two ocean-going passenger ships among the American merchant vessels that were U.S.-built and U.S.-flagged. In 1996, the ss Constitution was retired from service, leaving the ss Independence as the last U.S.-built passenger ocean liner to sail under the U.S. flag.

ACV had sought to replace the old vessels with new ships built in the U.S. Hawaii Senator Daniel Inouye helped by sponsoring Project America in the 1997 federal appropriations bill (Section 8109 of Public Law 105-56, the Department of Defense Appropriations Act for FY

\footnotetext{
${ }^{10}$ But see GAO, 2004 which examines the potential (rather than the ex post) impacts of granting NCLA a monopoly in the Hawaii interisland cruise market. The GAO focuses extensively on the history of the PVSA and other legal issues, particularly how the exemption from the foreign built requirement might affect the implementation of the PVSA, U.S. vessel documentation laws, or the Jones Act. It is noteworthy that while the U.S. International Trade Commission (USITC) periodically measures the welfare losses attributable to the Jones Act, it has yet to perform similar analysis on the Passenger Vessel Services Act because "the domestic cruise industry is too small to have measurable effects using the current [CGE] model.” (USITC, 1999, pg. 86, footnote \#4) The model is briefly described in the December 1995 Update.
} 
1998) to guarantee loans to ACV to build two state-of-the-art 70,000+ tons ocean-going cruise ships (Global Security.org, n.d). Work soon began on the first ship but was halted when ACV filed for Chapter 11 bankruptcy in October, 2001, citing a sharp decline in business after the 9/11 terrorist attacks. At that point, one ship was partially complete and parts for the second ship had been ordered. The suspension of construction on the two ships cost the U.S. taxpayers \$185 million in loan guarantees.

Norwegian Cruise Line (NCL) capitalized on ACV's demise in 2001 by starting its own Hawaii-based cruise tourism business. In December 2001, NCL began offering 7-day interisland cruises on its foreign-built and foreign-flagged ship, the Norwegian Star. To comply with the provisions of the PVSA, the Norwegian Star had to make a stop at a foreign port during its 7-day interisland cruise. NCL elected to make a lengthy roundtrip voyage to Fanning Island, an atoll of 13 square miles with a population of 1,600 in the Republic of Kiribati (Leidemann, 2002). This detour took more than 3 days of the 7-day Hawaiian islands cruise including a six hour layover at Fanning Island. NCL signed an agreement with the Kiribati government that granted the company exclusive visitation rights thus preempting possible encroachment by other cruise lines into its Hawaii business (Lo, 2004). ${ }^{11}$

By 2002, NCL had two ships deployed in Hawaii. In addition to the Norwegian Star, it also assigned the Norwegian Wind to spend much of the year in Hawaii to provide longer (alternating 10- and 11-day) interisland cruises with side trips to Fanning Island. Early financial returns from NCL's Hawaii-Fanning Island operations were encouraging. Ship yields were higher than in other, fiercely competitive markets such as the Caribbean (Duchemin, 2002).

Buoyed by its early success in Hawaii, NCL wanted to expand its offerings to include cruise itineraries that did not include side trip to Fanning Island. NCL purchased the partially completed Project America vessel and the parts for the second vessel in late 2002 and transported them to a shipyard in Germany to have the ships completed there (GAO, 2004, p. 9). To employ the two foreign-built vessels in strictly domestic service in Hawaii, NCL needed to obtain a waiver from the PVSA. Senator Inouye, who saw an opportunity to resurrect the Project America ships and the creation of 10,000 jobs in Hawaii, offered to help (Inouye, 2003; Wayne, 2003). He successfully inserted a provision in the Omnibus Appropriations Act of 2003 (Section 211, Public Law 108-7-February 20, 2003) that would allow NCL to complete the two Project America ships overseas. ${ }^{12}$ The two new ships and an existing foreign-built cruise ship would then be U.S.-flagged and permitted to sail exclusively in Hawaiian waters carrying the "Pride" brand under a newly formed U.S. subsidiary, NCL-America (NCLA). ${ }^{13}$ The General Accounting Office (GAO, 2004, p. 5) predicted that even though NCLA will have a monopoly in the wholly Hawaiian interisland cruise market "NCL will have little power to charge higher prices for its

\footnotetext{
${ }^{11}$ NCL could grant landing rights to other cruise lines and it did (GAO, 2004, p. 17,

Footnote \#31).

${ }^{12}$ However, the International Council of Cruise Lines did not support this measure and offered a broader proposal that would have allowed more cruise lines to participate (Yamanouchi, 2003). The final version of the legislation included a provision which prevented the three NCL U.S. flagged ships from being used in revenue service in the Caribbean, the Gulf of Mexico, or in Alaska. For an account of the politics behind this effort, see Wayne, December 14, 2003.

${ }^{13}$ Even though NCLA was required to operate the three Pride ships in "regular service"-defined as "primary service in which the ship is engaged on an annual basis"--in Hawaii, GAO opines that NCLA might be able to offer some service to the East and West coasts. The lawyers it consulted suggested that the ships must spend at least 51 percent of their time in Hawaii in order to comply with the exemption (GAO, 2004, pp.13-14). NCLA never used its Pride ships in regular service between U.S. west coast ports and Hawaii.
} 
exclusive itineraries because of the competition it will face from cruise itineraries offered by other lines that still include Hawaii, similar types of cruises in other areas, and land based vacations in Hawaii and elsewhere." GAO based its prediction on a 2002 Federal Trade Commission study of the cruise market (FTC, 2002). ${ }^{14}$ Skeptical analysts expressed doubt that NCLA could run its Hawaii operation profitably because of the higher costs associated with U.S. flag status (GAO, 2004, p. 26). ${ }^{15}$

With the exemption secured, NCLA introduced three 2000+ passenger capacity vessels between July, 2004 and June, 2006 to provide exclusive 7-day Hawaii interisland cruises (See Figure 1 for the time line of NCL's operations in Hawaii). The Pride of Aloha, formerly the Norwegian Sky registered in the Bahamas, was introduced on July 4, 2004. ${ }^{16}$ NCLA introduced the Pride of America in July, 2005 and the Pride of Hawaii in June, 2006. The company described its Hawaii operations as the "premium-priced Hawaii trade." (February 28, 2006 Financial Press Release) A major travel agency-Regal Travel—was promoting a 7-day Pride of Aloha interisland cruise “from $\$ 879$ per person” compared to a 10-day cruise on the Norwegian Wind to Fanning Islands for $\$ 719$ (The Honolulu Advertiser, July 11, 2004, p. E2.) However, the rapid expansion of capacity contributed to massive financial losses forcing the company to deflag two of its Pride vessels from U.S. registry in 2008 and redeploy them to Europe and Florida. ${ }^{17}$ This left the Pride of America as the last "American" cruise ship. ${ }^{18}$ The company noted that the Pride of America was profitable and expected NCLA to be profitable "with a onevessel scenario." (Dingeman, 2008).

NCL placed the blame for its earlier financial problems on depressed cruise prices in part on its own decision to expand capacity too rapidly, ${ }^{19}$ but in its application for federal government help assigned most of the blame on the "unprecedented" increase in competition from foreign

\footnotetext{
${ }^{14}$ But FTC (2002) actually stated the following: "Nevertheless, cruising is differentiated from other forms of vacations. Despite some evidence that the cruise lines consider land based vacations serious competitive threats (and vice-versa), the cruise lines' primary competitive focus is on each other. The evidence also shows that the cruise lines expend significant effort to monitor (to the best of their ability) each other's prices, deployments, and other behavior, and that only occasionally do they closely monitor the price or capacity of non-cruise vacation options."

${ }^{15}$ NCLA opined that labor costs for its U.S. flag operations would likely be 100 to 150 percent higher than labor costs for its foreign flag operations (GAO, 2004, p. 23). GAO's own investigation indicated that labor costs were about 70 percent higher on U.S. flagged vessels (GAO, 2004, p. 23, footnote \#38).

${ }^{16}$ Just before the deployment of the Pride of Aloha, NCL terminated the Norwegian Star's 7-day cruises to the Fanning Island (April, 2004) and redeployed the ship to the U.S. mainland.

${ }^{17}$ Separate financial reports for its Hawaii operation are not available as NCL only releases consolidated financial reports. See, for instance, http://www.ncl.com/csimages/473/1017/Q42007ER-ToBWireIII.pdf NCL reported net losses of \$227 million for calendar year 2007 and \$130.9 million for calendar year 2006 (at http://www.ncl.com/nclweb/cruiser/cmsPages.html?pageId=InvPR_022808.) It reported a net income of $\$ 16.2$ million for 2005 and a loss of $\$ 8.7$ million for 2004. If we focus only on operating income (loss), the company reported positive operating income for all four years. The largest non-operating expense item was interest.

${ }^{18}$ NCLA was also plagued by serious service problems (Toth, 2004; Arakawa, June 6, 2005). Poor service was not unrelated to NCL's staffing problems. From the very beginning, NCL had trouble recruiting, training, and retaining its all-U.S. citizen staff (Yamanouchi, 2004; Arakawa, 2005). In December 2007, the Pride of Aloha also failed a health inspection by the U.S. Centers for Disease Control and Prevention (CDC, 2007; "NCL's Pride of Aloha fails health inspection.”). The CDC cited a long list (67) of violations that required corrective action. See also Better Business Bureau of Hawaii's "unsatisfactory" rating for NCLA at http://hawaii.bbb.org/ViewReport.aspx?lnk=http\%3a\%2f\%2fhawaii.bbb.org\%2freport\%2f1076\%2f27000996\&biz= $27000996 \& b b b=1076$

$\frac{27}{19}$ "It is clear that the addition of capacity - both ours and our foreign-flag competitors - has outstripped demand in the short term, and we are not achieving the pricing needed to support our higher U.S.-flag operating costs." (February 28, 2007 Press Release) See also Dingeman, April 11, 2007, p. A2.
} 
cruise ships particularly those offering 15-day round-trip cruises from the U.S. west coast that were making token stops in Ensenada, Mexico to comply with the PVSA (Homeland Security, 2007, pp. 65488-65489; Camire, February 11, 2008; Dingeman, February 27, 2007) ${ }^{20}$. The nearterm prospects for the company did not appear to be encouraging as the company observed in its February 26, 2007 Financial Press Release: “Looking ahead, we face the challenge of an unprecedented 1.6 million capacity days of low-cost foreign-flag competition in the Hawaii trade during 2007, and published signs of further increases in 2008. We, therefore, are closely examining all options in our efforts to bring NCL America to profitability, and to reduce the negative impact of NCL America on the overall group result. The challenges in Hawaii, coupled with the default of a concessionaire in Q4, and the further weakening of the U.S. dollar, produced very disappointing results for both the quarter and the year.” In April, 2007, the company announced that it would deflag the Pride of Hawaii from U.S. registry and relocate her to Europe in February, 2008. ${ }^{21}$ In the following month the company announced the replacement of the managing director of operations in Hawaii (Arakawa \& Dingeman, 2007). Then in August, NCL announced that it had worked out a deal to obtain a \$1 billion cash infusion from one of the nation's largest equity companies, Apollo Management LP (Wiles, August 18, 2007). ${ }^{22}$ In February 2008, the company announced that it planned to deflag the Pride of Aloha and redeploy her from Hawaii by the end of May. In reviewing the events of the past year, the company's February 11, 2008 Press Release explained that “Our Hawaii business has been extraordinarily difficult, and although we have progressively established a stable operation, delivering a good product in a great destination, the overall price level in the market has been driven down to a significant degree by an unprecedented expansion of capacity from low-cost, foreign-flag ships based on the West Coast operating domestic Hawaii itineraries that the Customs Service has indicated are legally the preserve of U.S. flag ships.” The company indicated that it would keep the Pride of America in Hawaii through 2010.

\section{Lobbying to Make the PVSA More Protectionist}

NCLA lobbied the U.S. Maritime Administration and CBP to reinterpret the PVSA to make it more difficult for foreign cruise ships to carry passengers from U.S. west coast ports to Hawaii by requiring them to spend more time in foreign ports. In November 2007, Customs and Border Protection (CBP) published a notice of "proposed interpretation" in the Federal Register announcing a possible rule change that would require a foreign-flagged vessel carrying passengers between U.S. ports (Homeland Security, 2007):

1.) to stop at a foreign port for at least 48 hours;

\footnotetext{
${ }^{20}$ Public Law 108-7, February 20, 2003, 117 Stat.79 and Public Law 105-56, October 8, 1997 stipulates that the first ship was to be completed by no later than January 1, 2005 and the second ship no later than January 1, 2008, and that a third (existing foreign cruise ship) must be U.S. flagged and introduced into service no later than two years after the first newly constructed ship. As it turned out, the existing foreign flagged ship (Pride of Aloha) was placed first into service due to the delay in the completion of the first Project America vessel—Pride of America — when it was partially sunk in a German shipyard during a storm. If NCLA had followed the schedule set forth in the legislation, the three Pride vessels would have been introduced over a slightly longer period. Whether that would have been sufficient to stem the red ink is unknown.

${ }^{21}$ The company said that moving the Pride of Hawaii to Europe was a "temporary withdrawal." (Dingeman, April 11, 2007, p. A2.) The enabling legislation is silent on whether or not the ship could be brought back to Hawaii under U.S. registry once it was deflagged.

${ }^{22}$ Apollo Management received 50 percent ownership interest in NCL.
} 
2.) port time in foreign ports must be more than 50 percent of the time at U.S. ports of call; and,

3.) passengers must be permitted to go ashore temporarily at the foreign ports

More than 90 percent of the 358 comments received by CBP opposed the proposed rule change. $^{23}$

To placate opponents, NCLA agreed that the proposed rule change should only apply to round trip voyages from U.S. ports to Hawaii. In a letter to the CBP dated December 21, 2007 (Yamamoto, 2007) NCLA wrote “...the proposed interpretation should be clarified so that its scope is limited to vessels operating roundtrip voyages from U.S. ports that include Hawaii port calls...Such a limitation protects U.S. flag passenger vessel interests without prejudicing U.S. port interests. In contrast, an application of the proposed interpretation to 'any itinerary' would needlessly harm U.S. port interests unrelated to Hawaii without any countervailing benefit to U.S.-flag passenger vessel

interests." Strikingly, NCLA failed to mention the potential effect of the proposed rule change on consumer welfare.

In July, 2008, Homeland Security submitted to the White House Office of Management and Budget (OMB) on behalf of CBP its revised proposal which states that foreign-flagged vessels engaged in regular service to Hawaii would be in violation of the PVSA unless: 1) the cumulative length of stay at foreign port(s) is more than 50 percent of the total amount of time spent at the intervening U.S. ports, and 2.) passengers are permitted to go ashore at the foreign port(s) (Dudley, 2008). ${ }^{24}$ On August, 13, 2008, OMB returned Homeland Security's proposal for reconsideration. ${ }^{25}$ OMB's Administrator of the Office of Information and Regulatory Affairs explained its decision as follows:

In the course of reviewing this draft proposed rule, the Office of Information and Regulatory Affairs has concluded that the draft does not meet several of the basic requirements of EO 12866 and Office of Management and Budget Circular A-4, which require "Federal agencies [to] promulgate only such regulations as are required by law, are necessary to interpret the law, or are made necessary by compelling public need, such as material failures of private markets to protect or improve the health and safety of the public, the environment, or the well-being of the American people.” Specifically, this proposal presents no market failure or compelling public need, omits a statement of the costs and benefits of the rulemaking, and does not include a discussion and analysis of regulatory alternatives, significant distributive impacts, or uncertainties." (Dudley, 2008)

Circular A-4 (September 17, 2003) ${ }^{26}$ describes in detail guidance to Federal agencies on the development of regulatory analysis as required under Section 6(a)(3)(c) of Executive Order 12866. "A good regulatory analysis should contain 3 basic elements (p. 2): (1) a statement of the need for the proposed action, ${ }^{27}$ (2) an examination of the alternative approaches, and (3) an

\footnotetext{
${ }^{23}$ Individual comments can be seen at http://www.regulations.gov; type in "USCBP- 2007-0098” in the Docket ID field. The largest number of comments were received from Alaska, California, and Maine. While Hawaii's Congressional delegation supported the proposed rule change, Hawaii Governor Linda Lingle and California Governor Arnold Schwarzenegger vigorously opposed it (Camire, April 5, 20

${ }^{24}$ Executive Order 12866 requires federal agencies to conduct a regulatory analysis "for economically significant regulatory actions... This requirement applies to proposals to rescind or modify existing rules as well as to make new rules."

${ }^{25}$ http://www.reginfo.gov/public/return/DHSCBP_Coastwise_Cruises_Return_Letter.pdf

${ }^{26}$ At http://www.whitehouse.gov/omb/circulars/a004/a-4.pdf

${ }^{27}$ The "need" for federal intervention may arise from "a statutory or judicial directive.” (A-4, p. 3) It can also arise (A-4, p. 4) because of "a significant market failure or to meet some other compelling public needs such as improving
} 
evaluation of the benefits and costs - quantitative and qualitative-of the proposed action and the main alternatives identified by the analysis.” CBP failed to comply with any of the three requirements to support a rule change to the PVSA. Circular A-4 further notes (p. 6) that "Government actions can be unintentionally harmful, and even useful regulations can impede market efficiency. For this reason, there is a presumption against certain types of regulatory action...” including “...controls on entry into employment or production...”

The Chief of Homeland Security's regulatory branch opined that an economic analysis of the proposed rule change was unnecessary (Sutton, 2008). OMB disagreed. OMB's decision was greeted with relief by the American Association of Port Authorities and Cruise Lines International Association. However, the issue is not dead. NCLA announced that it would try again to get the rule changed after CBP complies with OMB's regulatory requirements (Sharp, August 16, 2008; Blair, August 29, 2008).

\section{The Merits of NCLA's Claims}

NCLA blamed its financial difficulties on depressed cruise ticket prices due to unfair competition from foreign flagged cruise ships operating mostly 15-day round trip cruises from the U.S. west coast to Hawaii in violation of the PVSA. To evaluate NCLA's claim, we begin by comparing the development of cruise tourism in Hawaii by NCL and the west coast to Hawaii cruise trade by other North American cruise companies between 2004 and 2007 under the rules of existing PVSA regulations. We wish to ascertain if cruise voyages to Hawaii from the U.S. west coast offered by foreign flagged cruise ships were the primary cause of depressed NCLA ticket prices in Hawaii and the company’s financial difficulties.

The data on cruise voyages and passengers come from the U.S. Department of Transportation, Maritime Administration (MARAD). ${ }^{28}$ The data contains complete micro-level data on individual cruise ship sailings from North American ports between 2004 and the end of the second quarter of 2008. Our analysis focuses mostly on full year data between 2004 and 2007. MARAD did not compile comparable data sets for the years before 2004. There are a total of 17,827 records of individual cruise ship sailings between 2004 and year-end 2007. Each entry lists (1) the name of the cruise line, (2) the name of the cruise ship, (3) the date of departure, (4) the port from which the ship departed, (5) the ship's destination, (6) the number of nights away, (7) the number of passengers on the vessel, (8) the vessel's normal passenger capacity, (9) the vessel's maximum passenger capacity, (9) total passenger nights = (6) x (7), and (10) which quarter (e.g. Q1, Q2, Q3, and Q4) of the year. A cruise ship that leaves Los Angeles to cruise the Hawaiian waters would be recorded as departing Los Angeles with a destination of Hawaii; even though it may call at several ports in Hawaii on a journey (say, Honolulu and Kahului), subsequent departures from the Hawaii ports would not be recorded as additional departures. Likewise a NCL vessel that leaves Honolulu and stops at several Neighbor Island ports would be recorded as departing from "Honolulu" with a destination of "Hawaii”. For Hawaii, we have individual vessel data on 728 cruise ship sailings "to Hawaii” between 2004 and 2007 including 385 by NCLA's three U.S. flagged Pride vessels (Pride of Aloha, Pride of America and Pride of Hawaii), and 103 by NCL's foreign flagged vessels (Norwegian Star and Norwegian Wind) which were required by the PVSA to make a stop at a foreign port (e.g. Fanning Island) on each

governmental processes or promoting intangible values such as distributional fairness or privacy.” The primary emphasis is on enhancing economic efficiency.

${ }^{28}$ At http://www.marad.dot.gov/marad_statistics/index.html 
inter-island cruise. ${ }^{29}$ From this data set, we were able to reconstruct the complete sailing records for the five NCL vessels in Hawaii. Thus, we have a seamless history of the operations of each NCL vessel and thus the company's cruise business in Hawaii between 2004 and 2007. However, the data set does not contain any financial information such as cruise prices, operating revenues and expenses, and so on.

Table 1 shows departures of cruise ships and passengers to Hawaii between 2004 and 2007.

Table 1

West Coast vs. NCL Vessels in Hawaii: 2004-2007

\begin{tabular}{|c|c|c|c|c|c|c|}
\hline \multicolumn{7}{|c|}{ \# of Sailings } \\
\hline & S.D., L.A & Ensenada & Total & "Pride" & N. Star & Total \\
\hline Year & \& Seattle & + \& Vancouver & $=\mathrm{W}$.Coast & Vessels + & \& N. Wind & $=$ NCL Vessels \\
\hline 2004 & 27 & 11 & 38 & 26 & 40 & 66 \\
\hline 2005 & 36 & 4 & 40 & 76 & 35 & 111 \\
\hline 2006 & 40 & 5 & 45 & 131 & 20 & 151 \\
\hline 2007 & 52 & 5 & 57 & 151 & 10 & 161 \\
\hline \multicolumn{7}{|c|}{ Change From } \\
\hline 2004 & +25 & -6 & +19 & +125 & -29 & +95 \\
\hline \multicolumn{7}{|c|}{$\frac{\# \text { of Passengers }}{\text { (in '000) }}$} \\
\hline 2004 & 43 & 21 & 64 & 52 & 82 & 134 \\
\hline 2005 & 63 & 8 & 71 & 156 & 63 & 219 \\
\hline 2006 & 76 & 10 & 86 & 276 & 35 & 311 \\
\hline 2007 & 98 & 8 & 106 & 351 & 17 & 368 \\
\hline \multicolumn{7}{|c|}{ Change From } \\
\hline 2004 & +55 & -13 & +42 & +299 & -65 & +234 \\
\hline
\end{tabular}

${ }^{a}$ Note: Excludes NCL trans-pacific voyages and additional inter-island trips by foreign carriers after initial arrival in Hawaii. S.D.=San Diego and L.A.=Los Angeles

${ }^{b}$ Source: U.S. Department of Transportation, Maritime Administration (MARAD), Cruise Statistics, at http://www.marad.dot.gov/marad_statistics/index.html

The number of cruise ships and passengers departing to Hawaii from the west coast did increase between 2004 and 2007 and the increase was greatest between 2006 and 2007 when NCL was complaining loudest about unfair foreign competition. However, the number of trips and passengers carried by NCL America's Pride vessels grew much more. There was a net gain of 42,000 passengers from the west coast between 2004 and 2007 (the increase from U.S. ports-Los Angeles, San Diego, and Seattle-- minus the decrease from foreign ports--Ensenada, Mexico and Vancouver, British Columbia which are not subject to the PVSA). NCL's Pride vessels

\footnotetext{
${ }^{29}$ The three Pride vessels made 7-day interisland cruises. Beginning in October, 2007, the Pride of Aloha was assigned to alternating 10 and 11 day Fanning Island cruises after the Norwegian Wind was quietly pulled from Hawaii service after April, 2007. Just before it was deployed to Miami, Florida in May 2008, the Pride of Aloha also offered 10 and 11 day interisland cruises. The Norwegian Star made 7-day interisland cruises with side trips to Fanning Island while the Norwegian Wind made alternating 10 and 11 day cruises that included Fanning Island.
} 
carried 299,000 more passengers in Hawaii in 2007 than in 2004, but the company lost 65,000 passengers on its Fanning Island itineraries when it withdrew the Norwegian Star (2004) and the Norwegian Wind (2007) from Fanning Island service for a net gain of 234,000 passengers. In 2007, NCL carried almost 370,000 passengers in Hawaii, but the number was not close to the 520,000 that were initially expected (Tobin, 2003). Most of the sailings originating from Ensenada and Vancouver were one-way cruises. ${ }^{30}$

Still the number of foreign cruise ship sailings from the U.S. west coast to Hawaii did increase between 2004 and 2007. However, for these sailings to financially harm NCLA's exclusive Hawaii-only cruises requires that the 15-day round trip cruises between the U.S. west coast and Hawaii and NCLA's 7-day Hawaii interisland only cruises be in the same market-i.e. they compete for the same customers. Evidence below suggests that they are not.

\subsection{Are NCLA Hawaii Cruises and U.S. West Coast to Hawaii Cruises Good Substitutes?}

Two goods are in the same market if they are good substitutes. Passengers who arrive in Hawaii from the west coast on a cruise ship spend only 5 days in Hawaii and 10 days "At Sea”; by contrast those who arrive by air to board NCLA's Pride vessels in Hawaii spend 7 days cruising the islands and an additional 2 to 3 days before and after the cruise vacationing in Hawaii (DBEDT, 2007 Annual Research Report, p. 125.) For those taking the 15-day round-trip cruise, the cruise ship is the primary “destination”. By contrast, for those taking the Pride of America and staying a few extra days enjoying a land-based vacation in Hawaii either before or after the cruise, Hawaii is the primary "destination”. The two itineraries arguably are not competing for the same customers. Indeed, as Table 2 shows, few people take lengthy cruises.

Table 2

North American Cruise Passengers by Cruise Duration: 2004-2007 Number of Passengers

Cruise Length
6 days or less
Exactly 7 days
8-13 days
14-16 days
17 days and over
Total

Cruise Length

6 days or less

Exactly 7 days

8-13 days

14-16 days

17 days and over

Total

${ }^{\text {a }}$ Source: MARAD, Cruise Statistics

$\begin{array}{llll}2004 & 2005 & 2006 & 2007 \\ 3,093,853 & 3,361,483 & 3,504,153 & 3,864,885 \\ 5,057,473 & 4,999,054 & 5,092,319 & 4,859,770 \\ 1,029,111 & 1,119,901 & 1,106,695 & 1,207,872 \\ 187,048 & 221,716 & 204,277 & 277,060 \\ 50,832 & 45,034 & 63,478 & 78,996 \\ 9,418,317 & 9,747,188 & 9,970,922 & 10,288,583\end{array}$

\% Distribution

$\begin{array}{llll}2004 & 2005 & 2006 & 2007 \\ 32.85 \% & 34.49 \% & 35.14 \% & 37.56 \% \\ 53.70 \% & 51.29 \% & 51.07 \% & 47.23 \% \\ 10.93 \% & 11.49 \% & 11.10 \% & 11.74 \% \\ 1.99 \% & 2.27 \% & 2.05 \% & 2.69 \% \\ 0.54 \% & 0.46 \% & 0.64 \% & 0.77 \% \\ 100.00 \% & 100.00 \% & 100.00 \% & 100.00 \%\end{array}$

\footnotetext{
30 They disembark passengers in Hawaii and return to the west coast with new passengers who flew to Hawaii to catch the ships. Table 1 does not include sailings and passengers from these subsequent voyages.
} 
In 2007, less than three percent of all cruise passengers in North America took cruise trips of 14 to 16 days duration compared to nearly fifty percent who took 7-day cruises. A closer substitute to NCLA's 7-day Hawaii interisland cruises may well be other 7-day cruises in North America and not the 15-day west coast to Hawaii round trip cruises. What would be the relevant counterfactual if foreign cruise lines are discouraged from offering cruises to Hawaii from U.S. ports from the west coast? We argue that they are likely to offer more cruises of similar trip duration from nearby foreign cruise ports such as Ensenada, Mexico or Vancouver, Canada. ${ }^{31}$ Consumers would be worse off because they have to incur higher cost of getting to and from the ship's homeport; that means there will be fewer passengers taking cruises to Hawaii. Moreover, the economic rents that were formerly reaped by the U.S. west coast port cities from homeporting these ships will now be transferred to port economies in Mexico and Canada. The scenario will likely be the opposite of what happened in Seattle and Vancouver beginning in the late 1990s when Seattle expanded rapidly as a home-port to cruise ships sailing to Alaska. The number of cruise ship departures from Seattle increased from 6 in 1999 to 190 in 2007; by contrast the number of cruise ship departures from Vancouver fell from 309 to 275 during the same period. $^{32}$

Figure 2 displays the number of Pride vessel sailings as well as west-coast to Hawaii cruise ship quarterly sailings between 2004 and the first half of 2008. Seasonality is clearly evident in the figure. What is striking about the figure is that when NCLA reduced the number of sailings (i.e. capacity) in 2008, other cruise lines did not expand their west-coast to Hawaii offerings to fill at least some of the void left by the departure of the two Pride ships. Obviously, the other cruise companies did not believe that the two cruise itineraries were close substitutes.

Carnival Corporation - the world's largest cruise ship company-argues that "Our voyages are not the reason that NCL has a problem in Hawaii. It's a fundamentally flawed argument, because they are totally different products and price points. If we left [the Hawaii market], it wouldn't make any difference [to NCL's business]" (Del Rosso, 2008). An examination of cruise prices offered by the two companies supports Carnival's claim.

We have no direct observations of NCLA's actual cruise prices. Cruise pricing is quite complex and at any time there are a large number of prices that are offered in the market place (FTC, 2002, p. 5). In addition to price variations depending on cabin location and quality and time (i.e. month/season) of the year, there are early booking discounts, last minute deals, repeat guest credits, cabin upgrades and various other incentives to influence consumer behavior. Most cruise packages are sold through travel agents who can and some do offer their own price discounts (FTC, 2002, p. 5). A consistent, historical data set on Hawaii cruise prices is available from the Sunday edition of the Honolulu Star Bulletin (Travel Section) which obtains its information from a major travel agency in Honolulu (Didi Ah Yo’s Cruise Holiday Hawaii) that

\footnotetext{
${ }^{31}$ Ensenada, Mexico is about 85 miles from San Diego and about 200 miles from Los Angeles. Vancouver, British Columbia is about 150 miles from Seattle.

${ }^{32}$ Cruise data for Vancouver from the Vancouver Port Authority, Statistics Overview, 2002 to 2007 at http:www.portvancouver.com; cruise data from Seattle from the Port of Seattle at http://www.portseattle.org/seaport/cruise. Most of the departures from both ports—92\% from Seattle and 87\% from Vancouver, 2004-2007-went to Alaska. The number of cruise ship departures from Vancouver reached a peak of 342 in 2003. The decline in cruise ship departures from Vancouver has not been as great as night be for U.S. ports if the reinterpretation of the PVSA were implemented because consumers who want to take 7-day one-way cruises to Alaska or one-way cruises from the Pacific Northwest to San Francisco and Los Angeles must still depart from Vancouver instead of from Seattle under current PVSA rules.
} 
specializes in the sale of cruise packages. ${ }^{33}$ The fares listed are based on the lowest cabin category for one person based on double-occupancy and do not include port fees and taxes. Figure 3 displays the weekly Honolulu Star Bulletin series for trip ticket prices for NCL and for Carnival Cruise Line cruises “to Hawaii” beginning in July, 2003. Carnival operates primarily (circa) 15-day round trip cruises from the west coast to Hawaii; NCL's ticket prices include those for Hawaii-Fanning Island cruises, but most of its cruises after 2004 were 7-day wholly interisland cruises. ${ }^{34}$ Figure 3 shows that while round-trip ticket prices from the west coast to Hawaii on Carnival vessels were pretty flat during this entire period, ticket prices for NCL spiked downward after the introduction of each new Pride vessel and remained lower than before. Finally, after the Pride of Hawaii and the Pride of Aloha were redeployed in early 2008, NCL ticket prices rose sharply. By comparison, Carnival's prices did not decline even as NCL's prices fell after 2004; nor did they rise in tandem with NCL's cruise prices in 2008. The simple correlation between the two price series is -.059. Thus the price data from the two cruise companies further suggests that the two cruise products are in separate markets.

Figure 3 also provides strong evidence that NCLA's short-term financial difficulties can be attributed to its own decision to deploy too much capacity too quickly. Table 3 shows that in 2009 NCLA is a "premium priced" cruise ship company. Table 3 was constructed by compiling interisland cruise prices in Hawaii vis-à-vis cruise prices in other markets by carefully searching cruise line websites during the month of October, 2008 for future cruises. We confined our price searches to posted prices for the 7-day Pride of America Hawaii interisland cruises and those for 7-day cruises in other North American markets for all of 2009. Again, the comparisons are based on prices per person for the lowest (inside) cabin category (double-occupancy) excluding taxes and fees. Not all markets operate cruises for the entire year. Prices also varied by cruise line and by time of the year. Detailed price information by company, by market, and by time of year are available from the authors by request. In Table 3 we provide only the mean price (unweighted) per day for each market for 2009.

Table 3

$\begin{array}{ll}\text { Average Cruise Price Per Day for } & \text { 7-Day Cruises: } 2009 \\ \text { Market } & \text { Price Per Day } \\ \text { Hawaii } & \$ 198 \\ \text { Alaska } & 120 \\ \text { Canada-New England } & 140 \\ \text { Southern Caribbean } & 101 \\ \text { Western Caribbean } & 96 \\ \text { Eastern Caribbean } & 99 \\ \text { Bermuda } & 100 \\ \text { Bahamas } & 114 \\ \text { Mexico } & 148\end{array}$

${ }^{\text {a }}$ Note: Lowest price (double occupancy) for inside cabin, excluding port fees and taxes. The unweighted average of the non-Hawaii market prices is $\$ 114.75$.

${ }^{\mathrm{b}}$ Sources: Cruise company websites for 2009 scheduled cruises.

\footnotetext{
33 These are available on microfilm at Hamilton Library, University of Hawaii at Manoa.

${ }^{34}$ In 200535 out of 111 NCL cruises in Hawaii were Fanning Island cruises; in 2007, slightly over 10 of 161 NCL Hawaii cruises included Fanning Island in their itineraries.
} 
For 2009, the average cruise price per day in the 7-day Hawaii interisland cruise market is much higher than prices in other markets of the same trip duration. The General Accounting Office (GAO, 2004, p. 5) was wrong when it predicted that NCL will have little power to charge higher prices for its exclusive interisland itineraries. Of course NCLA has to charge a premium price to cover its higher cost of employing U.S. labor on its ships. Nonetheless, the company's November 8, 2008 Press Release noted that "Our Hawaii operation is now profitable." 35 In December, 2008, the company announced that it had decided to extend the Pride of America's stay in Hawaii under U.S. flag registry through January, 2012 (Honolulu Advertiser, December 12, 2008). It would hardly seem necessary to make the PVSA even more protectionist when the company has finally figured out how to run a profitable domestic cruise ship company after a difficult beginning.

\subsection{Reinterpreting the PVSA Only to Apply to the Hawaii Trade}

NCLA had hoped that supporting a rule change that applies only to foreign cruise ships sailing to Hawaii would soften objections from mainland port cities that were not involved in the Hawaii cruise trade. Again, NCLA was wrong in its analysis. Cruise tourism is the quintessential "footloose" industry. Cruise ships are constantly being moved between markets from one year to the next and even within a given calendar year thus making individual cruise markets highly contestable (see, for example, Jainchill, May 21, 2008; September 22, 2008; and November 11, 2008). Consider Alaska's one million passenger cruise market which operates between mid-May and mid-September. Cruise ships that sail in Alaska during its short cruise season are deployed to other markets after the season. For example, in 2007 alone, NCL's Norwegian Sun sailed in Alaska, the Panama Canal, Hawaii, Pacific Coast, and in the Western Caribbean (from Miami and New Orleans). Table 4 shows the number of cruise ship sailings to Hawaii from the west coast between 2004 and 2007:

Table 4

Foreign Flagged Cruise Ship Sailings from the West Coast to Hawaii: 2004-07 From From

\begin{tabular}{|c|c|c|c|}
\hline \multirow{2}{*}{\multicolumn{4}{|c|}{ San Diego, L.A. \& Seattle }} \\
\hline & & & \\
\hline Jan.-May & 13 & 5 & 18 \\
\hline June-Aug. & 0 & 0 & 0 \\
\hline Sept.-Dec. & 14 & 6 & 20 \\
\hline \multicolumn{4}{|l|}{2005} \\
\hline Jan.-May & 19 & 0 & 19 \\
\hline June-Aug. & 0 & 0 & 0 \\
\hline Sept.-Dec. & 17 & 4 & 21 \\
\hline \multicolumn{4}{|l|}{2006} \\
\hline Jan.-May & 22 & 1 & 23 \\
\hline June-Aug. & 0 & 0 & 0 \\
\hline Sept.-Dec. & 18 & 4 & 22 \\
\hline
\end{tabular}

\footnotetext{
35 at http://www.ncl.com/nclweb/pressroom/pressRelease.html?storyCode=PR 110608; see also Jainchill, November 7, 2008. The "stabilization of our staffing" (i.e. control of its payroll and related costs) in NCLA operations was prominently mentioned as one of the reasons for the company's improved financial performance and outlook. NCL’s February 28, 2008 Financial Press Release.
} 
2007

$\begin{array}{lccc}\text { Jan.-May } & 24 & 2 & 26 \\ \text { June-Aug. } & 5 & 0 & 5 \\ \text { Sept.-Dec. } & 23 & 3 & 26 \\ \text { Source: U.S. Department of Transportation, Maritime Administration (MARAD), Cruise } \\ \text { Stistics, at http://www.marad.dot.gov/marad_statistics/index.html }\end{array}$

The number of cruise voyages by foreign cruise vessels to Hawaii from the west coast fell to zero during the months of June to August between 2004 and 2006 as ships were redeployed to Alaska; a smaller ship was assigned to ply the Hawaii route in $2007 .{ }^{36}$ Indeed, in May 2006, NCL sent its own Hawaii-based, foreign-flagged Norwegian Wind to Alaska and returned her to Hawaii in September after the short Alaska cruise season was over. The MARAD data show that between 2004 and the end of the second quarter in 2008, there were a total of 32 separate cruise ships that sailed in Hawaii and 25 of them also cruised in Alaska during the same period. The two markets are linked on the supply side. The redeployment of ships from Alaska to Hawaii during Alaska's "off season" increases supply and depresses cruise prices from the west coast to Hawaii, ceteris paribus. Similarly, cruise ticket prices in Alaska are lower than would be otherwise during its peak season as ships that could be in Hawaii are sent off to Alaska and increase total cruise ship capacity there. As demand for cruise tourism is believed to be price elastic (GAO, 2004; FTC, 2002) consumers and the economies of Alaska and Hawaii benefit from this flexible allocation of ship capacity. By allocating ships to markets that yield the highest return, economic efficiency is enhanced. If foreign cruise ships cannot profitably come back to Hawaii because of a more protectionist PVSA, the number of ships that can profitably sail in Alaska might also be reduced. Consumers may have to pay higher prices for Alaska cruises in the summer and higher prices for west coast to Hawaii cruises at other times of the year if the proposed narrower reinterpretation of the PVSA were adopted. In sum, NCLA's proposed remedy to limit the rule change only to cruise voyages to Hawaii will continue to "prejudice other cruise ports on the mainland."

\section{Conclusion: Is it Time to Repeal the Passenger Vessel Services Act?}

Since the 1960s there has been growing interest in America to assess the economic impacts of government regulations. As a result, we have gained greater awareness of the welfare losses attributable to the proliferation of both economic and social regulations. Hahn (1998) has suggested a number of federal laws and programs "that should be targets for elimination" among them the Jones Act. Perhaps because its economic imprint on the U.S. economy is small relative to the much larger impacts produced by the Jones Act on domestic freight shipments, the companion Passenger Vessel Services Act has largely escaped public scrutiny. But no longer. The PVSA has become widely publicized in the U.S. recently because of Norwegian Cruise Line America's efforts to persuade Customs and Border Protection to make the PVSA even more protectionist in order to save its lone "American" cruise ship based in Hawaii from foreign competition. The analysis in this paper shows that NCLA's petition has no merit.

It is obvious that the current interpretation of the PVSA allows foreign cruise lines to violate the original intent of the law when it was first passed 123 years ago to protect U.S. maritime commerce from foreign shipping. But public sentiment toward continued economic regulation of

\footnotetext{
${ }^{36}$ The numbers for 2005 do not include one westbound voyage by the Pride of America departing on July 9, 2005 from San Diego to Hawaii; the vessel was en route to Hawaii to begin her inaugural cruise season in Hawaii.
} 
many industries has changed since the 1970s as it became widely known that industry economic regulation more often than not benefit a few firms at the expense of the public at large.

Transparently, the PVSA increases costs to producers and consumers of cruise tourism services in North America. It limits the cruise options available to consumers. The PVSA also confers rents to U.S. cruise ports that are located close to foreign ports and transfers rents from U.S. ports to foreign ports. The effort by NCLA to make the PVSA even more protectionist will likely further reduce consumer welfare and America's national income.

The Cruise Lines International Association (CLIA, 2007) polled its own members on their sentiments toward the potential repeal of the PVSA and reported that "While a reformed Passenger Vessel Services Act might add some new U.S. ports to cruise itineraries, most of our members believe that this would not be significant, especially in light of the restrictions that likely would be attached.” Thus CLIA is currently not advocating a change to the PVSA.

What compensating benefit is obtained by keeping the PVSA in its current interpretation? The obvious answer is if the law advances America's defense and national security. By unilaterally and suddenly deflagging two of its Pride vessels from U.S. registry, NCLA demonstrated that its U.S. flagged vessels do not meet the objectives of America's coastwise laws by "providing reliable domestic shipping service and the existence of a maritime capability that is completely subject to national control in times of war or national emergency." ${ }^{37}$ It is noteworthy that after Hurricane Katrina devastated the Gulf Coast, Homeland Security did not commandeer a NCLA U.S. flagged vessel but instead chartered three cruise ships from Carnival Cruise Lines for six months to house up to 7,000 refugees (FEMA, 2005; MSNBC.com, September 3, 2005). NCLA can also unilaterally and suddenly deflag its last remaining U.S.flagged vessel, the Pride of America, and shut down its Hawaii operations as it has threatened to and as it did with its Fanning Island operations (Schaefers, February 13, 2008). This paper has demonstrated that NCLA's reasons for making the PVSA more restrictive are not supported by empirical evidence. The next step would be to conduct a thorough study to ascertain the full costs and benefits of the PVSA to the entire U.S. and whether or not this 123 year old law should be repealed.

\section{References}

Arakawa, L. (2005). NCL learns from Aloha launch. The Honolulu Advertiser, 6 June. p. c1. Arakawa, L.\& Dingeman, R. (2007). NCL Cruise Line Changes Leadership in Hawaii. The Honolulu Advertiser, 25 May. p. a1.

Blair, C. (2008). NCL says it will try again to get federal rule changed. Pacific Business News, 29 Aug. p. 21.

Blair, R. \& Mak, J. 2008. Saving the Last American Cruise Ship. Milken Institute Review, $4^{\text {th }}$ quarter, p. 50-57.

Camire, D. 2008a. Rule change could alter cruise industry. The Honolulu Advertiser, 11 Feb. p. c1-c2.

Camire, D. 2008b. Cruise limits opposed again. The Honolulu Advertiser, 5 Apr. p. b2.

\footnotetext{
${ }^{37}$ MARAD, “By the Capes-A Primer on U.S. Coastwise Laws,” p. 2. The General Accounting Office (GAO, 2004, p. 5) opined that "NCL's exemption also provides some potential economic benefits including jobs for the U.S. maritime sector, and tax revenues.” However, GAO has not shown that this is the best way to create jobs and generate tax revenues.
} 
Cruise Line International Association (CLIA). (2007). Technical and Regulatory: Passenger Services Act [Online] Fort Lauderdale, FL: CLIA. Available at: http://www.cruising.org/industry/passenger_services_act.cfm

Cruise Line International Association (CLIA). (2008). 2008 CLIA Cruise Market Overview, Statistical Cruise Industry Data through 2007 [PDF file] Fort Lauderdale, FL: CLIA.

Available at: http://www.cruising.org/Press/overview2008/printPDF.cfm

Del Rosso, L. (2008). Cruise, port execs seek compromise on cabotage proposal. Travel Weekly, 18 Feb. Available at http://www.travelweekly.com

Dingeman, R. (2007a). NCL sailing in sea of red. The Honolulu Advertiser, 27 Feb. p. a1-a2.

Dingeman, Robbie. (2007b). Pride of Hawaii bids aloha in '08' The Honolulu Advertiser, 11 Apr. p. a1-a2.

Dingeman, R. (2008). Pride of America idle for Pearl Harbor work. The Honolulu Advertiser, 1 May. p. c1 and c5.

Duchemin, J. Cruise industry is keeping sagging tour industry afloat. The Honolulu Advertiser 8 Sept. p. F5.

Dudley, S. Letter to Mr. Gus Coldebella, Acting General Counsel and Regulatory Policy Office, Department of Homeland Security, Washington D.C. 20529. Washington, DC: OMB; 2008. Available at: http://www.reginfo.gov/public/return/DHSCBP_Coastwise_Cruises_Return_Letter.pdf

President of the United States. Executive Order 12866—Regulatory Planning and Review. Federal Register, 58 (190), 51735-51744.

Federal Trade Commission (FTC). (2002). Statement of the Federal Trade Commission Concerning Royal Caribbean Cruises, Ltd./P\&O Princess Cruises plc and Carnival Corporation/P\&O Princess Cruises plc, FTC File No. 021 0041, 4 October. Available at http://www.ftc.gov/os/2002/10/cruisestatement.htm

FEMA.(2005). Temporary Housing for Hurricane Katrina Evacuees Includes Cruise Ships, FEMA Reports, Release No. Q-05-204, 4 Sept. Available at http://www.fema.gov/news/newsrelease.fema?id=18606

Francois, J., Arce, H., Reinert, K. \& Flynn, J. (1996). Commercial Policy and the Domestic Carrying Trade. Canadian Journal of Economics, XXIX (1), 181-198.

Gibson, P. Cruise Operations Management, Boston: Butterworth- Heinemann, 2006.

GlobalSecurity.org. "Project America," at http://www.globalsecurity.org/military/systems/ship/project-america.htm

Hahn, R. (1998). Government Analysis of the Benefits and Costs of Regulation. Journal of Economic Perspectives, 12, (4), 201-210.

Inouye, D. (2003). Inouye Project America Provision to Promote U.S.-Flag Cruise Ships in Hawaii, Provision in Omnibus Appropriations Bill Will Boost Hawaii Tourism and Strengthen National Security, 17 Jan. Available at: http://inouye.senate.gov/03pr/20030121pr01.html Jainchill, J. (2008a). Crown Princess to drop Jamaica for 2009-2010 season. Travel Weekly Daily Bulletin, [internet] 19 Aug.

Available at: http://www.travelweekly.com.

Jainchill, J. (2008b). Celebrity to pull Millennium out of Australia. Travel Weekly Daily Bulletin, [internet] 22 Sept. Available at: http://www.travelweekly.com

Jainchill, J. (2008c). Overseas Markets Fuel Cruise Growth. Travel Weekly Daily Bulletin, 15 Oct. Available at: http://www.travelweekly.com 
Jainchill, J. (2008d). NCL ends losing streak with profitable quarter. Travel Weekly Daily Bulletin, [internet] 7 Nov. Available at: http://www.travelweekly.com

Jainchill, J. (2008e). High airfares and a bad economy sending ships back to U.S. ports. Travel Weekly Daily Bulletin, [internet] 11 Nov. Available at http://www.travelweekly.com

Jainchill, J. (2009). Ports law makes altering Mexico cruises difficult. Travel Weekly Daily Bulletin, [internet] 30 Apr. Available at http://www.travelweekly.com

Leidemann, M. (2004). Fanning's ship may have come in. The Honolulu Advertiser, 24 Jun. p. a1 and $\mathrm{a} 5$.

Lewis, D. (2003). Air Transportation: Industrial Organization and Regulation. Joel Mokyr, ed., Oxford Encyclopedia of Economic History, 1, p. 104-106.

Lo, C. Report from Kiribati. Honolulu Weekly, 14 (47), 6-9.

Mak, James. (2003). Water Transportation: Regulation. Joel Mokyr, ed., Oxford Encyclopedia of Economic History, 5, 254-256.

Mak, James. (2004). Tourism and the Economy, Understanding the Economics of Tourism, Honolulu: University of Hawaii Press.

MSNBC.com. (2005). Cruise ships chartered for refugees. MSNBC online, [internet] 3 Sept. Available at: http://www.msnbc.msn.com/id/9188316/

Norwegian Cruise Lines (NCL). (2008). NCL Corporation Announces Adjusts to Hawaii Fleet, Company announces Pride of America's deployment through 2010 Pride of Aloha to leave the fleet in May. Press Release. [online] issued 11 Feb. Available at http://www.ncl.com/nclweb/pressroom/pressRelease.html?storyCode=PR_021108

Norwegian Cruise Lines. NCL Financial Press Releases. [online] Available at http://www.ncl.com/nclweb/cruiser/cmsPages.html?pageId=FinancialPressRelease

Sloan, Gene. (n.d.). NCL's Pride of Aloha fails health inspection. USAToday.com. Available at: http://www.usatoday.com/travel/cruises/item.aspx?type=blog\&ak=49317882.blog

Office of Management and Budget (OMB). (2003). Circular A-4 17 Sept. Available at http://www.whitehouse.gov/omb/circulars/a004/a-4.pdf

Schaefers, A. (2008). NCL says presence in Hawaii’s waters at risk. The Honolulu Star Bulletin,13 (44), 13 Feb. Available at http://starbulletin.com/2008/02/13/news/story03.html

Sharp, D. (2008). Bid to reduce foreign cruise ships’ time in Isles rejected. The Honolulu Advertiser, 16 Aug. p. c3.

State of Hawaii Department of Business, Economic Development and Tourism (DBEDT). (2008). Annual Visitor Research Report 2007, Honolulu: DBEDT.

State of Hawaii Department of Business, Economic Development and Tourism (DBEDT). (2004). 2002 and 2003 Hawaii Cruise Industry Impact Study. Honolulu: Research and Economic Analysis Division, DBEDT, circa 2004.

Stigler, G. (1971). The Theory of Economic Regulation. Bell Journal of Economics, 2 (1), 3-21.

Stopford, M. (1997). Maritime Economics, Second Edition. London: Routledge.

Sutton, A. (2008). Rule may shorten cruise ship stops in Alaska. Anchorage Daily News, 11 Feb. Available at: http://www.and.com/185/story/31458.html

Tobin, R. (2003). Future of Hawaii Cruising Looks Bright. Travel Weekly Daily Bulletin, [internet] 7 Jul. Available at: http://www.twcrossroads.com

Toth, C. (2004). Progress cited on Pride of Aloha. The Honolulu Advertiser, 10 Sept.p. c1 and c3.

United States International Trade Commission (USITC). (1995). The Economic Effects of Significant U.S. Import Restraints: First Biennual Update, Publication 2935. 
United States International Trade Commission (USITC). (1999). The Economic Effects of Significant U.S. Import Restraints, Second Update 1999, Investigation No. 332-325, Publication 3201.

United States International Trade Commission (USITC). (2004). The Economic Effects of Significant U.S. Import Restraints, Fourth Update, Investigation No. 332-325, Publication 3701.

United States International Trade Commission (USITC). (2007). The Economic Effects of Significant U.S. Import Restraints: Fifth Update.

U.S. Department of Health and Human Services, Centers for Disease Control and Prevention. (2007). Vessel Sanitation Program: Inspection Detail Report, Pride of Aloha, Norwegian Cruise Lines, Inspection Date, 12/21/2007. Available at: http://wwwn.cdc.gov/vsp/InspectionQueryTool/Forms/InspectionDetailReport.aspx

U.S. Department of Homeland Security, Bureau of Customs and Border Protection (CBP). (2007). 19 CFR Part 4, Hawaiian Coastwise Cruises, Federal Register, 72 (224) 21 Nov. p. 65487-65489. Available at: http://edocket.access.gpo.gov/2007/pdf/E7-22788pdf.

U.S. Department of Transportation, Maritime Administration (MARAD). (2008). By the CapesA Primer on U.S. Coastwise Laws. Available at: http://www.marad.dot.gov/Publications/primer_laws.html

U.S. Department of Transportation, Maritime Administration (MARAD). (2008). North American Cruise Statistics Snapshot, 2nd Quarter. Washington D.C.: Office of Policy and Plans.

United States General Accounting Office (GAO). (2004). Maritime Law Exemption, Exemption Provides Limited Competitive Advantage, but Barriers to Further Entry Under U.S. Flag Remain. Report to the Chairman, Committee on Commerce, Science, and Transportation U.S. Senate.

Wayne, L. (2003). Political Savvy Gets U.S. Flags On Foreign Ship. New York Times Online, 14 Dec. Available at: http://www.nytimes.com

White, L. (1988). International Trade in Ocean Shipping Services: The United States and the World, Cambridge, MA: American Enterprise Institute/Ballinger Publication.

Whitehurst, C. (1985). American Domestic Shipping in American Ships: Jones Act Costs, Benefits, and Options, Washington D.C.: American Enterprise Institute.

Wiles, G. (2007). NCL ponders leaving Hawaii. The Honolulu Advertiser, 18Aug. p. a1 and a9.

Winston, C. (1998). U.S. Industry Adjustment to Economic Deregulation. Journal of Economic Perspectives, 12 (3), Summer, 89-110.

Yamamoto, A. (2007). Hawaii Coastwise Cruises (USCBP-2007-0098), Comments in Response to Proposed Interpretation, Letter to The Honorable W. Ralph Basham, Commissioner, Customers and Border Protection, Honolulu: NCL America.

Yamanouchi, K. (2003). Cruise lines offer broader proposal. The Honolulu Advertiser, 1 Feb.p. a1 and a9.

Yamanouchi, K. (2004). Cruise line jobs not what some thought. The Honolulu Advertiser, 18 Apr. p. a1 and a6. 
Figure 1: Timelines for NCL Cruise Ship Operations in Hawaii (2004-2008)

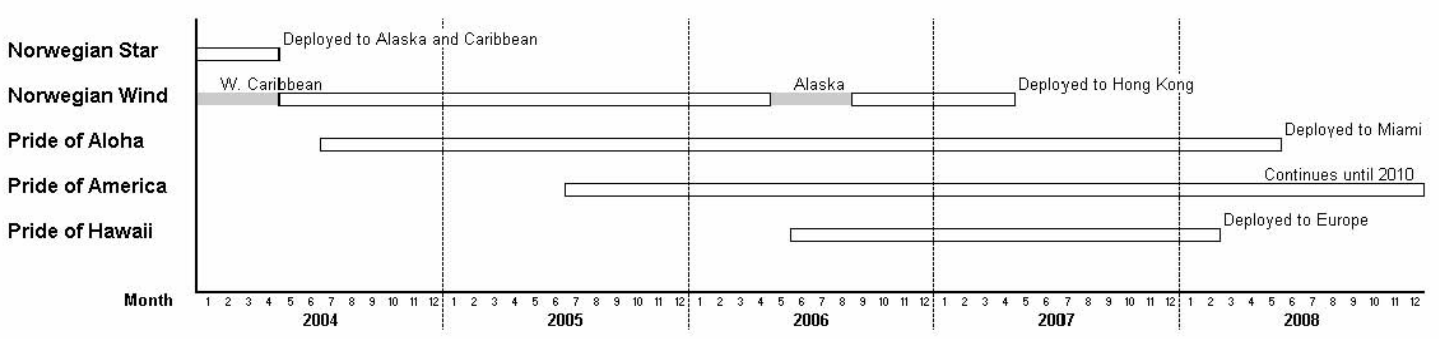

Figure 2: Number of Sailings

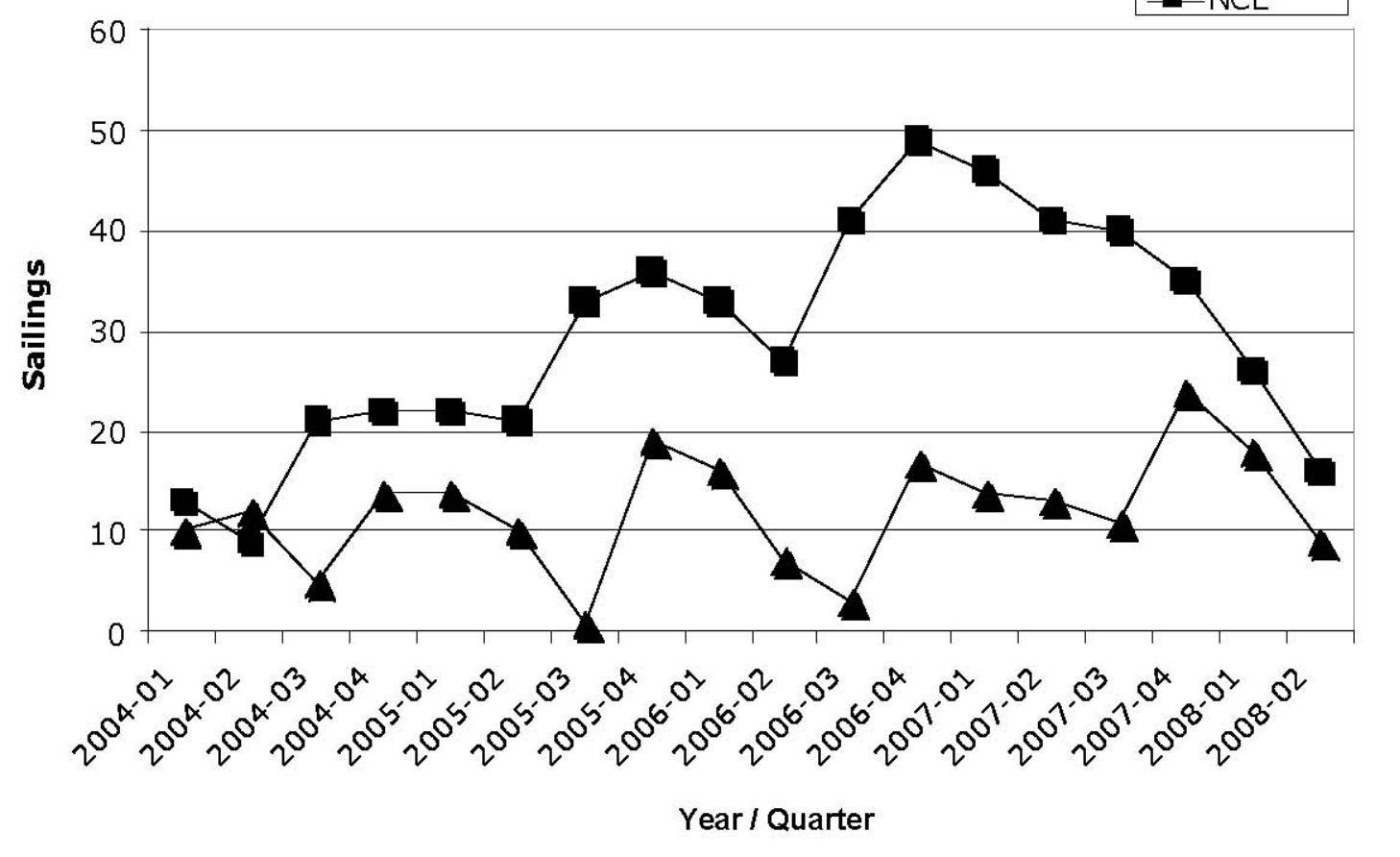




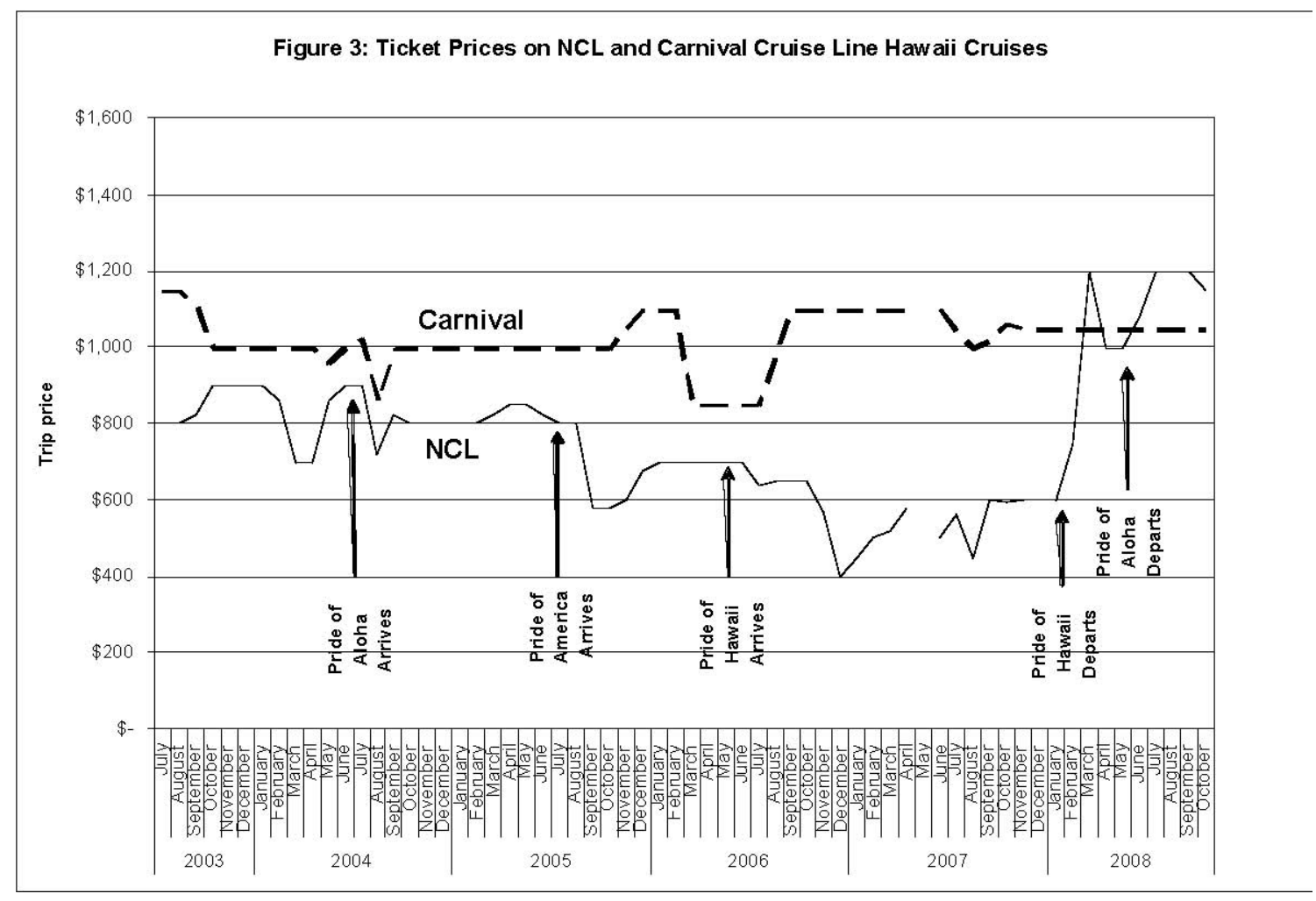


